\title{
OPTIMIZATION ON THE FINANCIAL MANAGEMENT OF THE BANK WITH GOAL PROGRAMMING MODEL
}

\author{
J. W. Chen ${ }^{1}$, W. S. Lam ${ }^{1,2, *}$ and W. H. Lam ${ }^{1,2}$ \\ ${ }^{1}$ Department of Physical and Mathematical Science, Faculty of Science, UniversitiTunku \\ Abdul Rahman, 31900 Kampar, Perak, Malaysia \\ ${ }^{2}$ Centre for Mathematical Sciences, Centre for Business and Management,UniversitiTunku \\ Abdul Rahman, 31900 Kampar, Perak, Malaysia
}

Published online: 10 November 2017

\begin{abstract}
Financial management is crucial for planning bank's asset and liabilities while taking consideration for multiple objectives. The objective of this study is to develop a Goal Programming (GP) model to optimize the financial management of Public Bank Berhad in Malaysia. Six goals from the financial statements namely total asset, total liability, total equity, profit, earning and optimum management items are investigated for the period from 2011 to 2015. The results of this study indicate that all six goals are fully achieved by using the GP model. This study is significant because it helps to develop a mathematical model to examine the financial strengths of Public Bank Berhad in Malaysia. Besides that, the potential improvement on liability, equity, profit, earning and optimum management item of Public Bank Berhadcan be identified in this study based on the deviation from the target value.
\end{abstract}

Keywords: Asset; Liability; Equity; Profit; Earning; Optimum Management Items.

Author Correspondence, e-mail: lamws@utar.edu.my

doi: http://dx.doi.org/10.4314/jfas.v9i6s.34 


\section{INTRODUCTION}

Financial management is essential for every company in order to support the quality and quantity of assets as well as taking into account of the company's liability for future planning [1]. For banking sectors, it is important to optimize the profit while minimizing risks that bring about severe losses to the bank [2]. Asset and liabilities management is defined as planning of asset and liability while considering multiple bank management objectives such as reducing risk and enhance liquidity of the bank [3]. Strategic decision is important because it will affect the future of a company [4-5]. The objective of this study is to develop a Goal Programming (GP) model to optimize the financial management of the bank. GP is a mathematical model which aims to solve multiple objectives decision-making problems [6-7]. Some common goals such as asset accumulation, liability reduction, profitability and optimum management items in the financial statement are the main concern in an organization such as bank and financial institution [2]. In this study, the financial statement in the annual report of Public Bank Berhad (PBBANK)from year 2011 to 2015 is investigated. PPBANK is one of the largest banking group in Malaysia and listed in Bursa Malaysia since 1967. It was founded in 1966 and has been operating for the past 50 years. In 2015, Public Bank Berhad was awarded as the Strongest Bank in Malaysia by balance sheet in the Asian Banker 500 Strongest Bank [8].

There are studies done on the bank's financial management by using mathematical model. A mathematical model is designed to determine the optimum management of asset and liabilities of the bank [1,9]. GP model is developed for generating the optimal solution for six goals which are asset accumulation, liability reduction, equity wealth, earning, profitability as well as optimum management items [2]. Besides that, the financial statement of United Bank of Africa (UBA) is studied using GP model [10].

In the field of financial management, GP model has been applied in portfolio selection [11-14], assets and liability management [15-17], financial planning [18-20], funding allocation [21] and bank balance sheet management [22]. The objective of this paper is to develop a GP model to optimize the financial management of PBBANK in Malaysia. Six goals from the financial statements identified in this study are total asset, total liability, total equity, profit, earning and optimum management items. The rest of the paper is organized as follows. The 
next section describes the data and methodology used in this study. Section 3 discusses about the empirical results of the study. Section 4 concludes the paper.

\section{METHODOLOGY}

In this study, the financial statement in the annual report of PBBANKfrom year 2011 to 2015 is investigated. A goal programming model is developed to optimize the financial management of the bank in order to achieve multiple goals. This study applies pre-emptive goal programming to determine the optimal solution. Pre-emptive method allows the decision makers to satisfy one goal at a time. It means that the first priority goal (P1) will be satisfied first then followed by the second priority goal (P2) and so on. The formulation for the goal programming model is as shown below

$$
\text { Minimize } z=\sum_{i=1}^{n}\left[p_{i}\left(d_{i}^{-}+d_{i}^{+}\right)\right]
$$

subject to

$$
\begin{gathered}
\sum_{j=1}^{m}\left(a_{i j} x_{j}+d_{i}^{-}-d_{i}^{+}\right)=g_{i} \\
x_{j}, d_{i}^{-}, d_{i}^{+} \geq 0
\end{gathered}
$$

where $p_{i}$ is the pre-emptive factor associated with each competitive goal in order of preference, $x_{j}$ is the decision variable for $j=1,2,3, \ldots ., m, a_{i j}$ represents the parameter of the decision variables, $d_{i}^{-}$represents the negative deviation variable from underachieving $\mathrm{i}^{\text {th }}$ goal, $d_{i}^{+}$represents the positive deviation variable from overachieving $\mathrm{i}^{\text {th }}$ goal and $g_{i}$ represents the target value or aspiration level for $\mathrm{i}^{\text {th }}$ goal.

Table 1 shows the summary of financial statement for PBBANK from year 2011 to year 2015 . The data includes asset, liability, equity, profit and earning. 
Table 1. Financial statement for PBBANK from year 2011 to 2015

\begin{tabular}{ccccccc}
\hline \multirow{6}{*}{ Goal } & $\mathbf{5}$ & $\mathbf{2}$ R'trillion & & Total \\
& $\mathbf{2 0 1 1}$ & $\mathbf{2 0 1 2}$ & $\mathbf{2 0 1 3}$ & $\mathbf{2 0 1 4}$ & $\mathbf{2 0 1 5}$ & \\
\hline Asset & 0.2494 & 0.2746 & 0.3057 & 0.3457 & 0.3638 & 1.5392 \\
Liability & 0.2339 & 0.2560 & 0.2845 & 0.3168 & 0.3315 & 1.4227 \\
Equity & 0.0156 & 0.0186 & 0.0212 & 0.0289 & 0.0323 & 0.1166 \\
Profit & 0.0035 & 0.0039 & 0.0041 & 0.0046 & 0.0051 & 0.0212 \\
Earnings & 0.0128 & 0.0141 & 0.0153 & 0.0169 & 0.0192 & 0.0781 \\
Total & 0.5152 & 0.5672 & 0.6308 & 0.7129 & 0.7519 & 3.1778
\end{tabular}

In this study, the priority of the goals is set as follows.

$P_{1}=$ First priority goal to maximize total asset

$P_{2}=$ Second priority goal to minimize total liabilities

$P_{3}=$ Third priority goal to maximize total equity

$P_{4}=$ Forth priority goal to maximize profitability

$P_{5}=$ Fifth priority goal to maximize earning

$P_{6}=$ Sixth priority goal to maximize the proportion of items' value in financial statement

The weight is assigned according to the value of an item in Table 1 . Therefore, Table 2 summarizes the weight in relation to the value of the goal based on Table 1.

Table 2. Weight in relation to the value of the goal

\begin{tabular}{|c|c|c|c|c|c|c|}
\hline \multirow{2}{*}{ Goal } & \multicolumn{5}{|c|}{ Weight in Relation to the Value of the Goal } & \multirow{2}{*}{ Total } \\
\hline & 2011 & 2012 & 2013 & 2014 & 2015 & \\
\hline Asset & 0.2494 & 0.2746 & 0.3057 & 0.3457 & 0.3638 & 1.5392 \\
\hline Liability & 0.2339 & 0.2560 & 0.2845 & 0.3168 & 0.3315 & 1.4227 \\
\hline Equity & 0.0156 & 0.0186 & 0.0212 & 0.0289 & 0.0323 & 0.1166 \\
\hline Profit & 0.0035 & 0.0039 & 0.0041 & 0.0046 & 0.0051 & 0.0212 \\
\hline Earnings & 0.0128 & 0.0141 & 0.0153 & 0.0169 & 0.0192 & 0.0781 \\
\hline Total & 0.5152 & 0.5672 & 0.6308 & 0.7129 & 0.7519 & 3.1778 \\
\hline
\end{tabular}

The decision variables are shown as follows:

$x_{1}=$ amount in year 2011 financial statement 
$x_{2}=$ amount in year 2012 financial statement

$x_{3}=$ amount in year 2013 financial statement

$x_{4}=$ amount in year 2014 financial statement

$x_{5}=$ amount in year 2015 financial statement

Six goal constraints are shown below:

Asset constraint:

$0.2494 x_{1}+0.2746 x_{2}+0.3057 x_{3}+0.3457 x_{4}+0.3638 x_{5} \geq 1.5392$

Liability constraint:

$0.2339 x_{1}+0.2560 x_{2}+0.2845 x_{3}+0.3168 x_{4}+0.3315 x_{5} \leq 1.4227$

Equity constraint:

$0.0156 x_{1}+0.0186 x_{2}+0.0212 x_{3}+0.0289 x_{4}+0.0323 x_{5} \geq 0.1166$

Profit constraint:

$0.0035 x_{1}+0.0039 x_{2}+0.0041 x_{3}+0.0046 x_{4}+0.0051 x_{5} \geq 0.0212$

Earning constraint:

$0.0128 x_{1}+0.0141 x_{2}+0.0153 x_{3}+0.0169 x_{4}+0.0192 x_{5} \geq 0.0781$

Financial statement managing constraint:

$0.5152 x_{1}+0.5672 x_{2}+0.6308 x_{3}+0.7129 x_{4}+0.7519 x_{5} \geq 3.1778$

$x_{1}, x_{2}, x_{3}, x_{4}, x_{5}, d_{1}^{+}, d_{2}^{+}, d_{3}^{+}, d_{4}^{+}, d_{5}^{+}, d_{6}^{+}, d_{1}, d_{\overline{2}}, d_{\overline{3}}, d_{\overline{4}}, d_{\overline{5}}, d_{\overline{6}} \geq 0$

Based on the goals identified, the goal programming model is formulated as follows:

Minimizing: $\quad P_{1} d_{1}^{-}+P_{2} d_{2}^{+}+P_{3} d_{3}+P_{4} d_{4}^{-}+P_{5} d_{5}+P_{6} d_{6}$

Subject to

$$
\begin{aligned}
& 0.2494 x_{1}+0.2746 x_{2}+0.3057 x_{3}+0.3457 x_{4}+0.3638 x_{5}+d_{1}^{-}-d_{1}^{+}=1.5392 \\
& 0.2339 x_{1}+0.2560 x_{2}+0.2845 x_{3}+0.3168 x_{4}+0.3315 x_{5}+d_{2}^{-}-d_{2}^{+}=1.4227 \\
& 0.0156 x_{1}+0.0186 x_{2}+0.0212 x_{3}+0.0289 x_{4}+0.0323 x_{5}+d_{3}^{-}-d_{3}^{+}=0.1166 \\
& 0.0035 x_{1}+0.0039 x_{2}+0.0041 x_{3}+0.0046 x_{4}+0.0051 x_{5}+d_{4}^{-}-d_{4}^{+}=0.0212
\end{aligned}
$$


$0.0128 x_{1}+0.0141 x_{2}+0.0153 x_{3}+0.0169 x_{4}+0.0192 x_{5}+d_{5}^{-}-d_{5}^{+}=0.0781$

$0.5152 x_{1}+0.5672 x_{2}+0.6308 x_{3}+0.7129 x_{4}+0.7519 x_{5}+d_{6}^{-}-d_{6}^{+}=3.1778$

In this study, LINGO version 16.0 is used to solve the goal programming model.

\section{RESULT AND DISCUSSION}

Table 3 presents the empirical result of goal achievement based on the optimal solution obtained from LINGO software.

Table 3. Goals achievement

\begin{tabular}{ccc}
\hline Goals Priority & Output Value & Goals Achievement \\
\hline P1 & $d_{1}^{-}=0$ & Fully Achieved \\
P2 & $d_{2}^{+}=0$ & Fully Achieved \\
P3 & $d_{3}^{-}=0$ & Fully Achieved \\
P4 & $d_{4}^{-}=0$ & Fully Achieved \\
P5 & $d_{5}^{-}=0$ & Fully Achieved \\
P6 & $d_{6}^{-}=0$ & Fully Achieved \\
\hline
\end{tabular}

As shown in Table 3, the output values are zero for all goals. This implies that all the goals are fully achieved for PBBANK. Table 4 shows the values of the deviation variables for all the goals. 
Table 4. Results of deviation variables

\begin{tabular}{ccc}
\hline Goals Priority & $d_{i}^{-}$ & $d_{i}^{+}$ \\
\hline P1 & 0 & 0 \\
P2 & $2.015794 \times 10^{-2}$ & 0 \\
P3 & 0 & $2.005794 \times 10^{-2}$ \\
P4 & 0 & $3.775701 \times 10^{-4}$ \\
P5 & 0 & $3.037049 \times 10^{-3}$ \\
P6 & 0 & $3.314619 \times 10^{-3}$ \\
\hline
\end{tabular}

Based on Table 4, for P1 which maximizes the total assets for the bank, the negative deviation $d_{1}^{-}=0$ indicates that first goal is fully achieved. The positive deviation $d_{1}^{+}=0$ shows that the total assets remain at RM1, 539,241 million. For P2 which is minimizing total liabilities, the positive deviation $d_{2}^{+}=0$ indicates the goal is achieved also. The negative deviation $d_{2}^{-}=2.015794 \times 10^{-2}$ implies that the liabilities can be decreased further by RM 0.02016 trillion. For P3 which maximizes the total equity, the goal is achieved and the total equity can be increased by RM 0.02006 trillion. The goal of maximizing profit (P4) can be achieved as well with an increment of RM 0.00038 trillion based on $d_{4}^{+}=3.775701 \times 10^{-4}$.

$d_{5}^{-}=0$ indicates that the goal for maximizing the earning is achieved. Based on the optimal solution, the total earning can be increased by RM 0.00304 trillion. The final goal (P6) is achieved as well with $d_{6}^{-}=0$ and $d_{6}^{+}=3.314619 \times 10^{-3}$. This shows that the proportion of the values of items in the financial statement can be increased further by RM 0.00331 trillion.

\section{CONCLUSION}

In this study, a goal programming model is developed to investigate the financial management of PBBANK in Malaysia. The results of this study show that all the goals are fully achieved. This implies that the financial performance of PBBANK is stable. Besides that, the potential improvement on liability, equity, profit, earning and optimum management item of Public 
Bank Berhad have been identified in this study based on the deviation from the target value. This study is significant because it helps to develop a mathematical model to examine the financial strengths of PBBANK in Malaysia. Furthermore, this study helps to determine the new target value for the goals for continuous improvement. The future research of this study should be extended to other countries by using GP model to optimize the financial management of the company.

\section{ACKNOWLEDGEMENTS}

This study is supported by Fundamental Research Grant Scheme FRGS/2/2014/SG04/UTAR/02/1.

\section{REFERENCES}

[1] Naderi S, Minouei M, Gashti H P. Asset and liability optimal management mathematical modeling for bank. Journal of Basic and Applied Scientific Research, 2013, 3(1):484-493

[2] Halim B A, Karim H A, Fahami N A, Mahad N F, Nordin S K S, Hassan N. Bank financial statement management using a goal programming model. Procedia-Social and Behavioral Sciences, 2015, 211:498-504

[3] Kosmidou K, Zopounidis C. An optimization scenario methodology for bank asset liability management. Operational Research International Journal, 2002, 2(2):279-287

[4] Moradi M, Janatifar H. Ranking of financial strategies based on linear goal programming and vikor. International Journal of Business Management and Economics, 2014, 1(1):16-23

[5] Kruger M. A goal programming approach to strategic bank balance sheet management. In SAS Global Forum 2011 Banking, Financial Services and Insurance Transition, 2011, pp. $1-11$

[6] Charnes A, Cooper W W, Ferguson R O. Optimal estimation of executive compensation by linear programming. Management Science, 1955, 1(2):138-151

[7] Winston W. L., Goldberg J. B. Operations research applications and algorithms. Belmont: Thomson Brooks/Cole, 2004 Corporate $\quad$ 2017, http://www.publicbankgroup.com/About-Us/Corporate-Profile 
[9] Jamshidinavid B, Mehri M. Designing a mathematical model of asset and liability management using goal programming in Eghtesad-e-Novin Bank. International Business Management, 2016, 10(7):1241-1248

[10] Arewa A, Owoputi J A, Torbira LL. Financial statement management, liability reduction and asset accumulation: An application of goal programming model to a Nigerian bank. International Journal of Financial Research, 2013, 4(4):83-90

[11] Lam W S, Saiful H J, Hamizun I. Portfolio optimization in enhanced index tracking with goal programming approach. AIP Conference Proceedings, 2014, 1614(1):968-972

[12] Hassan N, Lam W S, Shee Y S. Portfolio decision analysis with maximin criterion in the Malaysian stock market. Applied Mathematical Sciences, 2012, 6(110):5483-5486

[13] Lam W S, Lam W H. Strategic decision making in portfolio management with goal programming model. American Journal of Operations Management and Information Systems, $2016,1(1): 34-38$

[14] Saiful H J, Lam W H, Zaidi I. A new higher moment portfolio optimization model with conditional value at risk. International Journal of Operational Research, 2014, 21(4):451-465

[15] Giokas D, Vassiloglou M. A goal programming model for bank assets and liabilities. European Journal of Operations Research, 1991, 50(1):48-60

[16] Seshadri S, Khanna A H F, Wyle R. A method for strategic asset liability management with an application to the federal home loan bank of New York. Operations Research, 1999, 47(3):345-360

[17]Agarana M C, Bishop S A, Odetunmibi O A. Optimization of banks loan portfolio management using goal programming technique. International Journal of Research in Applied Natural Social Sciences, 2014, 2(8):43-52

[18] Lee S M, Chesser D L. Goal programming for portfolio selection. Journal of Portfolio Management, 1980, 6(3):22-26

[19] Baston R G. Financial planning using goal programming. Long Range Planning, 1989, 22(17):112-120

[20] Sharma J K, Sharma D K, Adeyeye J O. Optimal portfolio selection: A goal programming approach. Indian Journal of Finance and Research, 1995, 7(2):67-76

[21] Hassan N, Lim LL. Goal programming with utility function for funding allocation of a 
university library. Applied Mathematical Sciences, 2012, 6(110):5487-5493

[22] Thomas W. L., Daniel E. O. Advances in mathematical programming and financial planning. Connecticut: JAI Press Inc., 1993

How to cite this article:

Chen J W, Lam W S, Lam W H. Optimization on the Financial Management of the Bank with Goal Programming Model. J. Fundam. Appl. Sci., 2017, 9(6S), 442-451. 